\title{
TRANSLATING INTO SCOTS
}

\section{John Corbett}

ABSTRACT: This article gives a brief survey of the history of literary translation into Scots, a language variety closely related to but distinct from English. The survey begins with the development of Scots into a literary medium in the late Middle Ages. Gavin Douglas's 16th Century Scots version of the Aeneid was for many years the only version of the full text available to readers of English or Scots, and its reputation remains undimmed today. However, translation into Scots did not fade away as Scotland was drawn into political union with England. Rather, translation into Scots survived as a means of asserting a distinctive national identity, first of all within the framework of the British union, and later in opposition to it. For example, in the 18th Century, the many Scots translations of Horace construct Scotland as a non-metropolitan, classical idyll, and some 20th Century translations seek alternative cultural alliances, not with post-imperial England, but with revolutionary Russia, and latterly with post-colonial cultures. The survey demonstrates clearly that translation into Scots has always been a visible, political act, which is closely tied to changing constructions of Scottish identity.

KEYWORDS: translation; visibility; dialect.

RESUMO: Este artigo faz um breve levantamento da história da tradução literária para Scots, uma variedade de língua relacionada ao inglès, mas ao mesmo tempo distinta. Esse levantamento começa com o desenvolvimento do Scots como meio literário no fin da Idade Média A versão de Gavin Douglas da Eneida, em Scots do século XVI, fol por muitos

- University of Glasgow.

TRADTERM, 6, 2000, p. 39-59 
anos a única versão do texto completo disponivel para leitores de inglès ou Scots; sua reputaçâo permanece inalterada até hoje. No entanto. a traduçāo para Scots nāo desapareceu quando a Escócia foi unificada politicamente com a Inglaterra. Ao contrário, ela sobreviveu como meio de afirmação de uma identidade nacional distinta, primeiramente dentro do quadro da uniāo britânica e, posteriormente, em oposição a ela. Por exemplo, no século XVIII, as inúmeras traduçōes de Horácio para Scots constroem uma imagem idilica da Escócia, clássica e não metropolitana; enquanto algumas traduçōes do século XX buscam antes alianças culturais altemativas, não com a Inglaterra pós-imperial, mas com a Rússia revolucionária $e$, mais recentemente, com culturas pós-coloniais. $O$ artigo demonstra claramente que a traduçāo para Scots tem sido sempre um ato politico e visivel, intimamente ligado às diferentes construçōes da identidade escocesa.

UNITERMOS: tradução; visibilidade; dialeto.

\section{Introduction}

This article addresses two issues: first, it gives a flavour of the history of Scots translation, and in particular, how translation activity relates to political developments in Scotland. Translation into Scots has been going on for over 500 years, and it is a remarkably sensitive index of the way Scots try to make sense of their identity in terms of nationhood, locality and language. Secondly, the article discusses briefly the implications that translations into Scots have for the fledgling discipline of Translation Studies. Translation Studies broadens the traditional subject matter of scholars who look at translations. Translation Studies does not look primarily at linguistic and stylistic comparisons between source texts and their translations; rather it looks at ideological questions posed by translations, such as: why have certain texts been translated and others ignored? how do translated texts fit into the indigenous literary tradition of nations? do

TradTERm, 6, 2000, p. 39-59 
they support or subvert these traditions? how 'visible' is the translator?

Translations tell us much about power relations between cultures, the transmission of ideologies, the way that one culture appropriates and transforms the work of another culture, refashioning both the other culture and itself. A key debate within Translation Studies has centred on Venuti's claim that the history of translation into English, at least since the 18th Century, has been a process in which texts have been absorbed into the English literary canon, seamlessly, by translators who use standard English as a 'cloak of invisibility' (Venuti, 1995). In other words, the standard language erodes the sense of 'otherness' of translated texts. Venuti champions translators such as Ezra Pound who 'foreignise' their texts, for example by using non-standard grammar and dialect vocabulary. Pound in fact sometimes uses Scots terms in his translations to give them a sense of the archaic or exotic. This article questions where Venuti's theory of 'invisibility' leaves Scottish readers, for whom the dialect vocabulary may not be 'foreign' and who can point to a long and distinguished history of literary translation into Scots.

\section{2. 'Written in the Language of the Scottish Nation'}

The 'father' of Scots translation is Gavin Douglas, born around 1474, the fifth son of the Earl of Angus. A nobleman, career clergyman and eventually Bishop of Dunkeld, Douglas also wrote poetry, and in 1513 he completed his translation into Scots of all the books of Virgil's Aeneid. This was the first complete vernacular version of Virgil's epic in any variety of English and was to be the only version available for about another 70 years. There had been translation into Scots before Douglas. Mediaeval Scotland, like England, was a multilingual nation after all: Latin was the language of the Church and of education. French romances and chivalric treatises were the leisure reading of the Normanised aristocracy, and Gaelic (once the language of much of Scotland) was still the language of the highlands. The language of Douglas's Aeneid was a northern cousin of the English

TradTerm, 6. 2000, p. 39-59 
language, distinguished by a vocabulary and grammar that owed more than did southern speech to the Scandinavian dialects of Viking invaders and settlers. This Anglo-Norse creole had permeated the lowlands of Scotland in the 12th Century, when David 1 of Scotland invited Norman barons and their retinues north to settle and 'civilise' his country by establishing burghs and monasteries. From a toe-hold around the city of Edinburgh, 'Inglis' (as this northern variety was first called) eventually spread throughout southern Scotland. In time, it became the language of the Acts of the Scottish Parliament, and by the late 14th century there was original and translated literature in this northern tongue. No longer able to read their romances and treatises in French, nobles commissioned vernacular versions of works like Lancelot of the Laik or The Buik of the Law of Amys. The translators of these works, particularly the romances, had a mediaeval attitude to the process of translating; namely, if you didn't like what was in the original, change it. There is little sense of respecting the source text: the romances were part of a pool of general European culture, and the translator could adapt and transform as he felt fit.

Gavin Douglas's translation of the Aeneid is therefore remarkable for a variety of reasons. First, he attached to each book an original prologue, framing Virgil's work and commentating on how and why he was translating it. We learn in the first prologue that he has been inspired by the appallingly bad example set by the English printer and translator, William Caxton. Caxton's edited version of the epic concentrates on the love affair between Aeneas and Dido, Queen of Carthage, and he omits much of the battles and martial struggles. Caxton, in short, was treating Virgil's epic as one would treat a mediaeval romance, selecting and modifying. Douglas scorns this approach, and sets down for the first time in Scottish literature the principle of fidelity to the source text. As all translators know, fidelity to a source text is a terribly complex issue, but at least here it is being demanded, and Caxton's 'infidelity' is brutally attacked:

I red his wark with harmys at my hart, That syk a buke but sentens or engyne

TradTERM, 6, 2000, p. 39-59 
Suldbe intitillit eftir the poet dyvyne;

His ornate goldyn versis mair than gilt

I spittit for dispyte to se swa spilt

With sych a wyght, quhilk trewly be myne entent

Knew neuer thre wordis at al quhat Virgill ment -

Sa fer he chowpis I am constrenyt to flyte.

(Douglas, Eneados, I. Pro: 146-53)

To paraphrase, Douglas claims that he was cut to the quick when he read Caxton's work - to see the original golden verses spoiled by someone so evidently ignorant of Latin caused him to spit and to 'flyte', an old Scots word meaning to savage one's opponent in an argument. Douglas here sets out a manifesto for later translators, and effectively brings Scots translations into the modern age. Translators must respect and be true to their sources. Douglas was not, however, naive. He knew this would be a difficult. even impossible ideal to maintain. In particular, he realised that to capture the grandeur of Latin, the vernacular resources available to him would have to be supplemented by borrowings. And here, he makes another break with earlier tradition, in commenting that he 'had not other choice' but to borrow from other languages, including English ('sudroun'):

Nor it sa cleyn all sudroun I refuss

Bot som word I pronunce as nyghtbouris doys:

Lyke as in Latyn beyn Grew termys sum,

So me behufyt quhilum, or than be dum

Sum bastard Latyn, French or Inglys oyss

Guhar scant was Scottis - I had nane other choyss.

(Douglas, Eneados, 1. Pro: 113-8)

In making the distinction - unusual at the time - between 'Inglis' and 'Scottis' Douglas marks out his translation as a patriotic work, 'written' as he says elsewhere, 'in the language of the Scottish nation'. Douglas was not in any way anti-English (quite the opposite, in fact: he counted on English support for his clerical ambitions) but in translating the Aeneid he wished to honour his Roman source, Virgil; his noble patron, Sir Henry Sinclair;

TRADTERM, 6, 2000, p. 39-59 
and his country, Scotland. Ironically, the poem was completed on the eve of the battle of Flodden, a disastrous engagement with England, which saw the death of Douglas's patron as well as his king, James IV.

Even so, Douglas's Aeneid marks a period in which Scotland's sense of self-determination was confident and its literature in general reflected a distinctive national character. The translation is a testament to humanism with a distinctively Scottish accent. Other translations were to follow in the 16th Century. The closest follower of Douglas was John Bellenden, who translated five of Livy's books into Scots, but as the century wore on the tastes of translators turned away from classical works towards the work of contemporary European poets who were celebrating their nations in unashamedly vernacular verse. By the end of the sixteenth century, no less than James VI himself was writing original and translated poetry in Scots, and fostering around himself a group of poets who were translating from French and, now, Italian: Du Bellay, Du Bartas, Ariosto. Petrarch, even Machiavelli's $n$ Principe made it into Scots. James VI also wrote, when only a late teenager, a treatise for writers, discussing the problems of translation, and the competing demands of fidelity to the source text against the need for poetic invention. Douglas's lesson had been learnt but was obviously felt to be confining.

The beginning of the seventeenth century was dawning with a flowering of Scots translations; then, disaster struck. Elizabeth of England died childless, and James VI successfully negotiated for the throne of what was now the United Kingdom. The Scottish court, the poets and patrons of translations into Scots, were themselves literally translated south and quickly absorbed into the court in London. To commemorate this event, an ambitious playwright called William Shakespeare, wrote a play on a Scottish theme, based partly on a translation by John Bellenden of an earlier history of Scotland, originally written in Latin by Hector Boece. The last of James VI's court poets, William Drummond of Hawthornden, stayed on in Scotland, but even he adapted his written language to the norms of the English court. And by the time Sir Thomas Urquhart of Cromarty came to translate Rabelais, in the later 17th Century, the Scots tongue seemed appropriate TradTerm, 6, 2000, p. 39-59 
only for the speech of peasants, its written form represented as an archaic and incomprehensible babbling. It should all have ended there - but it didn't.

\section{A distant view of empire}

The Act of Union in 1707 was not a popular event in the Scotland of that time. Scotland had shared a monarch with England since the inception of the United Kingdom in 1603, but (with a brief interruption during Cromwell's government) Scotland had retained its own parliament in Edinburgh. Indeed, with the departure of the court to London in the 17th Century, the circle of lawyers and lawmakers in Edinburgh had assumed the roles of cultural patrons in Scotland. Until its latter days the Scottish parliament did little more than rubber stamp legislation coming from England, yet it served as an institutional focus for a sense of Scottish patriotism. It was dissolved in 1707, however, for reasons which bear limited but interesting comparisons with the political issues relating to European integration today.

Then the burning issues were sovereignty and religion. Many Protestant Scots approved of the English initiative in overthrowing the Catholic James VII in 1688, and eventually establishing the Hanoverians on the throne of the UK. Yet for the English, there was always the possibility of the exiled Stuarts trying to reestablish a power base in Scotland - and there were, of course, unsuccessful Jacobite rebellions in Scotland in 1715 and 1745. The Scottish middle classes had also suffered a tremendous financial loss in the Darien Scheme, a disastrous attempt to establish a Scottish colony in Panama in the 1690s in which many Scottish fortunes were invested and ruined. The Act of Union settlement paid off many of the debts incurred in the Darien Scheme - giving rise to Robert Burns's later line, 'We're bought and sold for English gold'. Finally, the Act of Union of 1707 opened up England as a free trade area for Scottish merchants, and gave access first to English markets, then imperial markets for Scottish goods. A popular Scottish stereotype became the young man who went to London to increase his fortune - the 'lad o' pairts' of

TRADTERM, 6, 2000, p. 39-59 
Scottish narratives, the 'Scotchman on the make' of English versions.

As is the case with European integration in the 1990's, there was a deep ambivalence in Scotland about the Act of Union in 1707, an ambivalence to do with relative loss of sovereignty balanced by the promise of economic advantage. There was also the problem of how Scottish identity could be reconstructed in a country which still regarded itself as a nation, but which had lost the apparatus of a state. Culturally, this ambivalence found expression in the Scots literary revival, spearheaded by an Edinburgh wig-maker, poet and bookseller, Allan Ramsay - father of the eminent portrait painter of the same name. For the first time since the Union of the Crowns in 1603, Ramsay popularised the use of Scots in poetry and drama - and translation.

Ramsay's literary career began in one of the many gentleman's clubs which were springing up over Europe. The Easy Club was an early Scottish example of this largely middle class explosion of social networking and civic and self-improvement. Such literary associations provided the opportunity to improve one's manners and conversation, while advancing one's position amongst one's peers and betters. Ramsay's adopted nickname in the Easy Club was 'Gavin Douglas', an early indication of his interest in (and self-identification with) the translator of the Aeneid. Significantly, Douglas's translation had been republished in Scotland in 1710, again raising the status of the Scots tongue. Ramsay's own Poems, first published in 1721, include five translations - or, as Ramsay more accurately styled them, 'imitations' of Horace's Odes, and they are singled out for our attention in Ramsay's Preface to this edition:

There are towards the End of this Miscellany, fix or six Imitations of Horace, which any acquainted with that $\mathrm{Au}$ thor will presently observe. - I have only snatched at his Thought and Method in gross, and dress'd them up in Scots, without confining my self to no more or no less; so that these are only to be reckoned a following of his Manner. (Ramsay, Poems; Preface: Martin and Oliver, eds., 1945: $\mathrm{xx})$

TRADTERM, 6, 2000, p. 39-59 
It is not difficult to account for much of the attraction that Horace held for Ramsay: the Scot was seduced by the authority of the classical poet, the fact that Horace combines provincialism with urbanity, and - crucially - with what was perceived as his familiar tone of voice. Horace, unlike Virgil, speaks to us directly, and a first-person construction of a poetic persona was well-suited to the literary revival of Scots, because for over a century Scots had been largely restricted to the spoken word, and its cultural expression was now mainly realised in folksong and oral tales. Translation from Horace allowed poets in Scots to extend the intellectual range of their verse while retaining their distinctive spoken voice. For example, in the final lines of Odes I. iii 'Sic te diva potens Cypri -' or 'Horace to Virgil, on his Taking a Voyage to Athens', Horace moves from expressing his anxiety for Virgil's safety at sea, to a more generalised concern for humanity's Promethean desire to provoke the gods. In Ramsay this becomes:

Prometheus ventur'd up and staw

A lowan coal frae Heaven's high ha';

Unsonsy thift, which feavers brought

In bikes, which fowk like sybous hought:

Then Death erst slaw began to ling.

And fast as haps to dart his sting.

Neist Dedalus must contradict

Nature forsooth, and feathers stick

Upon his back, syne upward streek,

And in at Jove's high winnocks keek,

While Hercules, wi's timber mell,

Plays rap upo' the yates o' Hell.

What is't man winna ettle at?

E'en wi' the Gods he'll bell the cat:

Tho' Jove be very laith to kill.

They winna let his bowt ly still. stole

burning; hall

unlucky

beehives; ontons; hoed

previously siow; gallop

hops

next

then

windows peek

with his wooden mallet

gates

won't attempt

loathe

(thunder)bolt

Horace's odes, for Ramsay, were not valuable in themselves. insofar as they had to be faithfully adhered to and reproduced as literally as possible; rather, they served as inspirational models for literary expression in Scots. In this, Horace's own persona 
was important, insofar as it corresponded with the aspirations of the Scottish bourgeoisie in the new 'North Britain' - philosophical, witty, familiar, urbane - their new geographical distance from the centre of power and influence regarded as a blessing rather than a curse.

Ramsay's Preface to the Poems of 1721 offers a strong justification for the use of Scots rather than English. He conventionally legitimises Scots by indicating a classical antecedent, the Doric Dialect of Theocritus', but he also considers that the linguistic relationship between English and Scots in the early eighteenth century favours Scots speakers, insofar as possession of two linguistic codes rather than one increases the range of vocabulary available to the poet. However, Ramsay's major reason for writing in Scots is hinted at in his admission that he knows no Latin:

Such Pedants as confine Learning to the critical Understanding of the dead Languages, while they are ignorant of the Beauties of their Mother Tongue, do not view me with a friendly Eye: But I'm even with them, when I tell them to their Faces, without Blushing, that I understand Horace but faintly in the Original, and yet can feast on his beautiful Thoughts dress'd in British; - and do not see any great Occasion for every Man's being made capable to translate the Classicks, when they are so elegantly done to his Hand. (Martin and Oliver, eds, 1945: xviii)

The reference to 'British' rather than 'English' suggests that Ramsay identifles the English tongue with the British state implicitly the function of his 'native Dialect', is to express his identity as a Scot. Politically, he was not an active Jacobite despite his membership of the Easy Club, he absented himself from Edinburgh during the 1715 uprising - but his desire for Scotland's political autonomy found expression in a sentimental nostalgia for the Jacobite cause. In this, as in so much else, Ramsay was the fore-runner of later Scots writers, including, of course, Robert Burns.

Recent scholarship on Scottish history and culture has argued that a strain of Jacobitism persisted in Scottish writing all TradTerm, 6, 2000, p. 39-59 
the way through from the Act of Union to the revival of Scottish nationalism in the 20th Century. This may well be true, but it is difficult to argue against the fact that such nationalist radicalism as there was found itself increasingly marginalised in the later eighteenth century and into the nineteenth. The Scottish middle classes largely adapted themselves to dual nationality British and Scottish - and took advantage of the opportunities afforded by Union with England within the British Empire.

Translations by British Scots took two main forms in the nineteenth century: some continued the classical vein established by Allan Ramsay and subsequent eighteenth century translators of Horace into Scots. However, the political force of the classicism became muted as time passed and the Union strengthened, and the rural aspect of the translations became cosier and more idealised. This transition parallels the general decline of the Scots Literary Revival into that populist cabbage-patch whimsy known as 'kailyard'. The last of the 'homespun Horaces' was James Logie Robertson (1846-1922), who, under the name 'Hugh Haliburton' published very diluted versions of Horace in the Scotsman newspaper, with great success. In 1882 a first collection of these verses appeared in book form. In Robertson's version of Horace's ode to Virgil, the two Roman poets are transformed into Scottish shepherds, and the Promethean theme is updated:

We flew a draigon: an' the spark

Obeys a baim if need is

child

But look at the mischeevous wark mishievous work

That's wrocht wi' thir torpeedies.

It's lang sin' pouther was fund oot:

But we've done weel oorsel' -

We've raised in dynamite. I doot,

The mucklest deil in hell.

wrought; torpedoes

(gun)powder

I believe

greatest devil

Ramsay's translation is at least an attempt to do some justice to the Promethean theme of his source text - the choice of octosyllabic couplets and the retention of mythological allusions testify to his seriousness. Robertson, on the other hand, opts for the ballad metre and translates a powerful condemnation of hu-

TRADTERM, 6, 2000, p. 39-59 
bris into a nostalgic regret for a pre-industrial idyll - an idyll represented in the late 19 th Century by the sentimental image of the Scottish highlands. Over the century and a half between Ramsay and Robertson, the meanings represented by Horace had changed: the witty, urbane cosmopolitan Horace that appealed to Ramsay is played down by Robertson in favour of Horace as a rustic, nostalgic moralist. The nineteenth century Horace in Scots was the kind of Horace you could take home to your granny, the kind of Horace that would be given the seal of approval by Church ministers and schoolteachers, and indeed that's who the translators tended to be.

\section{Mystic celts and balladeers}

Horace was by far the most popular writer translated into Scots in the first two centuries following the Act of Union; however, there were other trends in translation in this period, and I wish to mention them briefly. First of all, the most immediately influential Scottish work of this period was not written by Allan Ramsay or even Robert Burns but by James MacPherson, a Gael. MacPherson claimed to have collected and translated an epic of Gaelic poetry, an epic which was eventually published as the Ossian cycle of poems. MacPherson evidently embroidered and adapted and elaborated on Gaelic traditions in this verse cycle, but the impact of the Ossian poems in Scotland and particularly in Europe is difficult to overestimate. It was huge. The Ossian translations are from Gaelic into English, but their success further accelerated the growing interest in Scotland in native traditions, folk song and folk poetry. And translators like Robert Jamieson sought the wellsprings of the Scottish folk tradition in the native songs and ballads of Scandinavia and Germany. As Jamieson makes clear in his introduction to his contribution to Ilustrations of Northern Antiquities (1814) exposure to the northern European folksong tradition through translation is a voyage of self-discovery for Scots. Jamieson even stresses the linguistic similarity of Scots and the Scandinavian languages by interlacing one of his Swedish ballads with his Scots translation:

TRADTERM, 6, 2000, p. 39-59 
Ridder Wal sadlar up sin gāngare grä;

Sä rider han sig öfwer böljorna blä.

Sir Wal saddles up his gangar gray;

Sae rides he him over the billows (?) blae.

Och nær som han kom til en rinnande strôm,

Dær satt en næktergal i et træd, som sjōng.

And whan that he cam till a rinning stream,

There sat a nightingale in a tree, that sang.

'Sir Wal and Lisa Lyle'

(in Weber and Jamieson, 1814: 375)

This trend in tracing Scottish roots in northem Europe continued into the twentieth century with Sir Alexander Gray's translations of Scandinavian and German ballads and songs, and is an index of the continuing sense of national identity celebrated by Scottish translators. This strand of Scots translations is inherently inward-looking: the translators are actively seeking not a classical model for accommodation within a British imperial framework, but a cultural alliance with northern Europe which will support a distinctively Scottish sense of national identity. Effectively, the Anglo-Norse linguistic heritage of lowland Scotland is being drawn upon to construct a sense of self-hood in opposition to the Anglo-Saxon derived language and culture of southern England.

As the nineteenth century came to an end and the twentieth century began, the British Empire began to decline and eventually, after two World Wars, it fell. Always a pragmatic nation, Scotland began to re-examine its marriage with England, which was largely a marriage of economic convenience, and wonder if it would be better off getting a divorce. As the relationship has become more strained, some would argue that Scotland should even run away with that handsome young partner, the European Community, and just leave sorry old England to its own devices. That hasn't quite happened - we're still at the counselling stage, trying to work things through - but certainly in the twentieth century we have witnessed a revision in what being Scottish means,

TradTerm, 6, 2000, p. 39-59 
and this revision is also evident in the different types of translation into Scots.

\section{Plastic Scots for a Modern Age}

I wish to bring this brief survey of modern Scots translations up to date now with a look at two trends in twentieth century Scots translation: the Lallans tradition and what I'll call the modern vernacular tradition.

'Lallans' (Lowland Scots) was a term taken from Burns and popularised by Hugh MacDiarmid in the 1920s as part of an extremely self-conscious project to modernise Scottish politics and culture. MacDiarmid reacted against the tendency in Scots writing to be regressive and nostalgic - tendencies seen in both the classical and the ballad translations into Scots. MacDiarmid's own early writing draws on the folk tradition in Scots, but interleaves it with diverse cultural influences, including versions of German, Dutch and Russian poetry, usually adapted from English into a Scots which called upon resources from a range of locations and periods. MacDiarmid inaugurated a rigorously modernist period in Scottish translation, using a Scots that was initially celebrated (and later denounced) as 'synthetic' or 'plastic'.

An example of MacDiarmid's Scots can be seen in the opening lines adapted from an English translation of Aleksandr Blok's 'The Stranger', which MacDiarmid found in an anthology of contemporary Russian poetry and incorporated into his epic soliloquy. 'A Drunk Man Looks at the Thistle':

Of evenings hangs above the restaurant

A humid, wild and heavy air.

The Springtide spirit, brooding, pestilent,

Commands the drunken outcries there.

(Blok, trans., Duetsch and Yarmolinsky, ll 1-4)

At darknin' hings abune the howff

$A$ weet and wild and eisenin' air.

TradTERm, 6, 2000, p. 39-59 
Spring's spirit wi' its waesome sough

Rules owre the drucken stramash there.

(Deutsch \& Yarmolinsky, adapted MacDiarmid, 1l. 169-172)

MacDiarmid's success opened the floodgates for 'modern makars' to experiment with Scots translations of a whole swathe of modernist poets. Politically as well as culturally, Russian poets have appealed to the generally left-wing consensus among Scottish poets, and we have fine Scots translations of Blok, Mayakovsky and others by such as Sydney Goodsir Smith and Edwin Morgan. These translations are perhaps the epitome of this desire by twentieth century Scots translators to extend the Scottish language and influence the ideas of a culture by appropriating the literature of another culture which seemed, at least. to be ideologically compatible. Thus Edwin Morgan translates Mayakovsky ("May Day 'lines 1-7):

\section{MAY DAY \\ (A Wee Sang for Lads and Lassies)}

Leafikje leafikie green!

We ken the winter's awa

Let's gang

whaur the swire's as bricht's a preen

know, gone

go

valley: bright: pin me

and you

and us an aa.

all

Lallans translations, then, have an overt political agenda, which in Scotland tends to combine nationalism with socialism: MacDiarmid famously was expelled from the SNP for his communism, and expelled from the Communist Party for his nationalism. Translation is crucial to the Lallans project - Scots is linked via translation to newly prestigious cultures (not just the classical and northern European folk traditions) and the literary medium is extended beyond the constraints of everyday speech by borrowing from the source languages, as well as by the coining of neologisms and the revival of archaisms. In this redefinition of 
Scottish cultural ties and indeed of the Scots language itself, the links with England are weakened, and Scotland is again distanced linguistically, politically and culturally from its British partner.

\section{The cult of the real}

There is, however, an ironic paradox in the Lallans project: in refashioning the 'language of the people' and inventing 'plastic Scots', the medium of translation is taken away from the everyday vernacular of the Scottish people. Lallans symbolises the language of the Scots even though no Scot would use a dense literary Lallans in their everyday speech and writing - and some writers in Scots are wary of Lallans for that reason. Some Scottish translators opt for a more faithful representation of the modern Scots vernacular and they eschew the borrowings, neologisms, archaisms, and sheer density of Scotticisms that mark out Lallans translations. Some translators - notably Edwin Morgan - move between the two camps: while his Mayakovsky translations are in an appropriately experimental Scots, his adaptation of Edmond Rostand's Cyrano de Bergerac is much closer to contemporary Glaswegian speech.

While Morgan blurs the distinction between Lallans and the vernacular, certain translators reject 'plastic' Scots in favour of a variety that constructs identity in regional and class terms, rather than in nationalist terms. In her introduction to her collection Wittgenstein's Web, Sheena Blackhall responds to critics who advise her to move beyond the speech of the north-east of Scotland. Her argument is that she sees Lallans (and implicitly the Scottish nation) as an artificial construct, and prefers the concrete realities of her Aberdeenshire locality and idiom. Wittgenstein's Web contains several stories adapted from Italian, including a rendition of Italo Calvino's 'Pesci Grossi, Pesci Piccoli'. Like many Scots translators since Ramsay, Blackhall acknowledges her debt to an English translation, in this case Archibald Colquhoun's 'Big Fish, Little Fish':

TradTerm, 6, 2000, p. 39-59 
BIG FISH, LITTLE FISH

Zefferino's father never got into bathing-dress. He stayed in rolled-up trousers and vest, with a white linen cap on his head, and never moved away from the rocks. He had a passion for limpets, the flat clams which stick to rocks and become with their very hard shells almost a part of the stone. To prise them off Zefferino's father used a knife, and every Sunday he would scrutinize the rocks on the headland one by one through his spectacled eyes. On he would go until his little basket was full of limpets; some he ate as soon as gathered, sucking the damp bitter pulp as if from a spoon; the rest he put into his basket. Every now and again he would raise his eyes, let them meander over the smooth sea and call out: 'Zefferino! Where are you?'

(Calvino, trans. Colquhoun, 1965)

\section{MUCKLE FUSH-TEENIE FUSH}

Zefferino's faither nivver wore dookers. He keepit on his rowed-up trooser legs an sark, wi a fite linen bunnet on his heid, an niwver traivelled awa frae the rocks. He'd a saft spot fur lempets, yon fat clams clappit teetle the rocks that grow (wi their byordinar teuch shells) near-like pairt o the steen. Tae yark them aff, Zefferino's faither made eese o a knife, an ilkie Sabbath he'd glower at the rocks on the heidlan, ane bi ane, throw his glaisses. He'd cairry on till his wee pailie wis fu o lempets: some he galloched doon as sune's he preed them, sookin the sappy wersh soss as if frae a speen; the lave he stappit inoo his pailie. llkie noo an again, he luikit up, his een reengin ower the smeeth sea, an skelloched, "Zefferinol Far are ye?"

(Colqhoun, adapted by Blackhall, 1996)

If Blackhall sites her sense of identity in a concrete rural locality rather than the problematical imagined national community, Tom Leonard's rewriting of William Carlos Williams's 'Just

TRADTERM, 6, 2000, p. 39-59 
to let you know' celebrates the 'real' voice of urban Scotland. Leonard says of Williams's poetry:

What 1 like about Williams is his presentation of voice as a fact, a fact in itself and as a factor in his relationship with the world as he heard it, listened to it, spoke it. That language is not simply an instrument of possession, a means of snooping round everything that is not itself - that's what I get from Williams.

(Leonard, 1976; reprinted 1984: 95)

Leonard's representation of urban Scots signifies a break from the middle-class representations of Scots which go back to the nineteenth century and beyond. He avoids quaint archaisms. neologisms and borrowings, preferring to devise a phonetic spelling which gives primacy to the spoken voice. His appropriation of Williams is part of his own agenda: to force us to reconsider the status of speech and the values - social, regional, national - which are imposed upon it. The translation goes:

Jist ti Let Yi No

(from the American of Carlos Williams)

ahv drank

thi speshlz

that wurrin

thi frij

$\mathrm{n}$ thit

yiwurr probbli

hodn back

furthi pahrti

awright

they wur great

thaht stroang

thaht cawld

TradTerm, 6, 2000, p. 39-59 
The modern translators into Scots vernaculars challenge the notion of Scottishness presented by the Lallans translators. The Lallans translators match the notion of the nation as an 'imagined community' by synthesising an 'imaginary national language' to cement it together. The vernacular translators sidestep the problem of defining the nation by focusing instead on the immediacies of class and region. What they have in common is (1) a mission to demonstrate that their chosen linguistic medium is capable of articulating favoured texts from other cultures, (2) a sense of autonomy from cultural trends south of the border, and kinship with cultures elsewhere, and (3) a political agenda that involves the definition and redefinition of what it means to be Scottish here and now.

\section{Implications for translation studies}

I'd like to conclude briefly by considering, as promised in the introduction, what a history of translation from a Scottish perspective can offer Translation Studies in general. I'll do this more by raising interesting questions than by providing reductive answers.

First of all, it is seriously misleading to consider Scottish translations from the perspective of the Anglo-American tradition. Lawrence Venuti's book The Translator's Invisibility traces the history of translation into English from an Anglo-American perspective, and its main argument is that standard English provides a cloak of invisibility for the translator which allows him or her to domesticate or familiarise the translation, so that it appears natural in the host culture. Venuti appeals for a translation strategy that allows for cultural difference to be expressed by using marked language - and the only appearance of Scots in his history is as a foreignising resource. Now there are many reasons why Hugh MacDiarmid or Allan Ramsay or Edwin Morgan use Scots in their translations, but it is difficult to argue that they are 'foreignising' their texts for their Scottish readers (although ironically many Scots will have difficulty in comprehending them!). The main plank of Venuti's argument rests on the

TRADTERM, 6, 2000, p. 39-59 
availability of a standard language to act as a cloak of invisibility. No standard variety of Scots ever evolved: translators into Scots therefore have no hiding place. Their political and cultural cards are always displayed on the table - which doesn't mean that all the cards are necessarily identical. Different varieties of Scots imply different political stances.

Scotland is obviously not unique in having this set of problems. Any society which constructs its sense of national identity around a language which is considered non-standard by a dominant culture is bound to find parallels with Scots

What I hope I've shown is that by focusing on one aspect of Scottish linguistic and literary production - translations into Scots - we can chart the awkwardness and tensions which are made manifest in the marriage between two of the nations which make up what is still, for the time being, the British state, and how, from century to century, they are partially resolved.

\section{References}

BASSNETT, S. (Ed.) (1997) Translating literature. DS Brewer.

BLACKHALL, S. (1996) Wittgenstein's web. GKD Press.

BUTHLAY, K. (Ed.) (1987) A drunk man looks at the Thistle, by Hugh MacDiarmid Scottish Academic Press.

COLDWELL, D. (Ed.) (1957-64) Virgil's Aeneid translated into Scottish verse by Gavin Douglas. Scottish Text Society.

Colguhoun, A. (1965) Big Fish, Little Fish by I. Calvino, In: TREVELYAN, R. (Ed.) Italian short stories 1/Racconti Italiani 1. Penguin. CORBETT, J. (1997) Language and Scottish literature. Edinburgh Univ. Press.

. (1999) Written in the Language of the Scottish nation. Multilingual Matters.

LEONARD, T. (1984) Intimate voices. Galloping Dog.

MARTIN, B. and OLIVER, J.W. (Ed.) (1945) The works of Allan Ramsay. Scottish Text Society, v. 1.

MORGAN, E. (1996) Collected translations. Carcanet.

ROBERTSON, J.L. ['Hugh Haliburton'] (1925) Horace in homespun. William Blackwood \& Sons.

TradTerm, 6, 2000, p. 39-59 
WEBER, H. and JAMIESON, R. (1814) Mustrations of northern antiquities. Ballantyne. VENUTI, L. (1995) The Translator's Invisibility. Routledge. 
